\title{
Needham Model Based Instructional Multimedia Material for Teaching Digital Logic Gates
}

\author{
Ming Foong Lee ${ }^{1 *}$, Siti Nursaadah Mat Yusoff ${ }^{2}$, King Hyiang $\operatorname{Tan}^{3}$ \\ ${ }^{1,2 \& 3}$ Universiti Tun Hussein Onn Malaysia, 86400 Parit Raja, Batu Pahat, MALAYSIA
}

DOI: https://doi.org/10.30880/jtet.2019.11.01.007

Received 26 $6^{\text {th }}$ August 2019; Accepted $19^{\text {th }}$ October 2019; Available online $31^{\text {st }}$ March 2019

\begin{abstract}
The purpose of this study was to design and develop an instructional multimedia for digital logics gate topic in Electrical and Electronic subject. This topic was chosen as the content-wise of this instructional media due to the teachers' recommendation. Teachers stated that students are facing difficulty to identify types, symbols, functions and completing the truth tables for logic gate. The failure of students to master this basic concept led them facing difficulty to solve problems involving combinational logic gate, which required students' skills to build equations, draw logic circuits and complete the truth table in order to get the circuit output. This instructional media was developed using constructivist theory approach, namely Needham Model. This model consists of five phases: orientation, generation of idea, restructuring of idea, application of idea, and reflection. Meanwhile, Three Product Development Life Cycle (PDLC) Phases (Design, Develop, and Review) was used as the research methodology for this study. This instructional media was developed using Microsoft Office Power Point 2007, Adobe Photoshop CS3, Photoscape and Edius 4. This study was divided into three main phases, namely (I) Need Analysis Phase, (II) Development of Instructional Media Phase, and (III) Instructional Media Evaluation Phase. At the Phase I, the user requirements for the instructional multimedia was identified for the purpose to design. Based on the findings at Phase I, the instructional media was developed at Phase II. At Phase III, the developed instructional multimedia was evaluated through the experts' validation and review from the aspect of pedagogy, engineering content-wise, and the multimedia elements. The findings showed that experts' feedback and comments for the instructional multimedia was positive. As a conclusion, teachers were encourages to use instructional multimedia based on Needham Model to enhance student performance in logic gate topic.
\end{abstract}

Keywords: Needham Model; product development life cycle; logic gates; instructional multimedia

\section{Introduction}

Today, there is a change occur in the learning and teaching (L\&T) process in the classroom. This change is geared towards the use of hardware and software in various media that are more attractive, more structured, more stimulating and more challenging. This introductory concept has brought a huge change in the classroom instruction. The use of instruction media with multimedia element in the $\mathrm{L} \& \mathrm{~T}$ process is a new approach of replacing the current traditional method by using power point slide presentation without any pedagogical element. Traditional power point presentation does not attract or stimulate the learning process because it does not involve the needs of students with different learning ability.

If the learning environment is unattractive, teachers' teaching methods and strategies that are not compatible with cognitive level or student needs will make it difficult for teachers to deliver knowledge to students. The less efficient teaching methods will make create the learning process that not able to achieve the learning objective being set. This causes the student unable to reinforce the new learnt concepts in depth and will lead them to the misconception situation (Leinsin, 2007). Furthermore, the use of instructional media play an important role in creating the conducive L\&T environment because it is able to attract students and assist them to understand subject matter easier an engaging learning 
environment created. All these make learning more effective to ensure students mastery the knowledge delivered by the teacher.

Multimedia material is an alternative to diversifying instructional media through multimedia technology approaches and giving exposure to students about the sophistication of today's multimedia technology (Zain, 2002). The process of designing and developing interactive multimedia materials requires appropriate instructional approach. Additionally, learning is an individual process (Abdullah, 1998). Students have different backgrounds and capabilities as well as different mastery skill. Instructional multimedia is capable of providing individualized, sensitive and personalize learning to the student's needs in their own control.

There are many types of instructional approach, one of the most widely used currently is constructivism theory. Needham Model is one of the learning model applying constructivism theory. Variously studies have shown that this learning approach is able to enhancing students' mastery level, for example in teaching engineering subjects, arts subjects and even science subjects (Lee \& Zainal, 2018). Moreover, previous findings also shown a significant improvement in students' achievement in applying constructivism theory in learning. For example, in teaching Mathematics (Laz \& Shafei, 2016), teaching Science and Scientific Thinking (Qarareh, 2016), teaching Business Statistics (Maheshwari \& Thomas, 2017).

Generally, the subject of Electricity and Electronics contains many topics that students can hardly understand because the theories, concepts and calculation in the subject content is abstract. Hence, to enhance student understanding for this subject, the delivery method in L\&T process should be modified from a traditional approach to exploration and self-discovery approaches through interactive multimedia materials that embedded with instructional design. The use of this kind of instruction media is able to involve students actively during the $\mathrm{L} \& \mathrm{~T}$ process. Based on the findings of preliminary study during the Need Analysis Phase (will discuss in detail at the following sub topic), it is found that students suffering with problems in learning digital logic gates among the topics in Electrical and Electronic subject.

Consequently, this study is conducted to design and develop an instructional multimedia in digital logic gates by applying the Needham Five Phases Model. The development of this interactive multimedia material integrates multimedia elements such as text, audio, video, animation and graphics to improve the effectiveness and ease of the students understanding the concepts in digital logic gates. Research questions were developed to achieve the objectives of this study,

- What are the features of an instructional multimedia material based on Needham Model for digital logic gates topic?

- How to develop the instructional multimedia material based on Needham Model for digital logic gates topic?

- What is the experts (pedagogical, subject matter and multimedia) evaluation on developed instructional multimedia?

\subsection{Needham Model}

Needham Model, also called Needham 5 Phase Model of Constructivism is a learning model was proposed by Richard Needham at 1987 in his work "Children Learning in Science Project". In this model, students can explore the ideas, compare with their own ideas and reflect the learning process they have experienced. The five phases of this model are orientation, generation of idea, restructuring of idea, application of idea, and reflection.

\subsubsection{Orientation}

This phase is aimed to attract students' attention and interest in order to motivating students to continue to be interested in the ongoing learning process. Teachers need to provide the learning atmosphere that able to motivate students to learn at this stage (Ab. Halim, 2007). For the purpose of encouraging discovery, students are given the option to explore information and control their learning process (Samin \& Mustapha, 2005).

\subsubsection{Generation of idea}

This phase aims to aware of the student's prior knowledge. The students' prior knowledge will be identified through suitable learning activities to encourage them recall their memories that related to new knowledge (Marimutu, 2004).

\subsubsection{Restructuring of idea}

This phase is intended to develop or modify the students existing knowledge or idea with an analytical or scientific idea, means students have the opportunity to modify the alternative idea in their mind to scientific ideas. New ideas will be presented in various forms that fit the learning progress of the students that may help students shaping the new concept. Students will be able to create definition, explain the concept, question about further explanation and justification and explanation on the new learning topic. 


\subsubsection{Application of idea}

This phase is intended to identify newly modified or built-in ideas of students can be applied in new situations. The concept has been built linked and developed in other fields or in the real world. Students will apply new knowledge by solving problems in new situations. This is aimed to create new understanding and encourage inquiry among students (Nail and Muthiah, 2005).

\subsubsection{Reflection}

This phase is aimed at assessing students' understanding and evaluating the same ideas as before changed. Selfassessment or motivational reward helps student's mastery knowledge and skills using the earlier ideas in the new learning environment. In addition, this phase also provide opportunity for students to evaluate their ideas and skills change. Students compare existing knowledge with new knowledge and reflect on the process learning that causes changes to their ideas. Students can also make reflection to see how far their original idea has changed. Teachers can use self-writing methods, group discussions and student's personal posts to research the level of understanding of students (Ab. Halim, 2006).

\section{Methodology}

The Product Development Life Cycle (PDLC) with three phases was used as the research design $\mathrm{n}$ this study. The three phases consist of Design, Develop, and Review. The detail for each phase is explained in Table 1. Meanwhile, Figure 1 illustrated the conceptual framework for this study.

Table 1-Three Phases of PDLC

\begin{tabular}{|c|c|c|}
\hline Phase & Detail & \\
\hline \multirow[t]{5}{*}{ Design } & Purpose & $\begin{array}{l}\text { : to conduct need analysis and design the instructional } \\
\text { multimedia }\end{array}$ \\
\hline & Sample & : 4 teachers and 31 students \\
\hline & Instrument & : interview questions \\
\hline & Analyses method & : Thematic analyses \& Descriptive Statistics \\
\hline & Theory behind & : Needham 5 Phases Model \\
\hline \multirow[t]{2}{*}{ Develop } & Purpose & : to develop the instructional multimedia \\
\hline & Software used & $\begin{array}{l}\text { : Microsoft Office Power Point 2007, Adobe Photoshop CS3, } \\
\text { Photoscape and Edius } 4\end{array}$ \\
\hline \multirow[t]{4}{*}{ Review } & Purpose & $\begin{array}{l}\text { to review and obtain the feedback from experts on develop } \\
\text { instructional multimedia from the aspects of pedagogical, } \\
\text { subject matter and multimedia. }\end{array}$ \\
\hline & Sample & : 3 experts in pedagogical, subject matter and multimedia \\
\hline & Instrument & : interview questions \\
\hline & Analyses method & : Thematic analyses \\
\hline
\end{tabular}

\section{Results and Discussion}

\subsection{Features of the Instructional Multimedia Material for Digital Logic Gates}

The needs analysis was conducted using interview and questionnaire. Interviews was conducted on four (4) Electronic teachers and eight (8) students whom have been taken the Electrical and Electronic courses (two students for each grade) and scored grade A, B, C and D in the final exam of Electrical and Electronic Principles. The need analysis was conducted in order to obtain information on features of the instructional multimedia material. Table 2 shows the findings gathered from interview and questionnaire. 


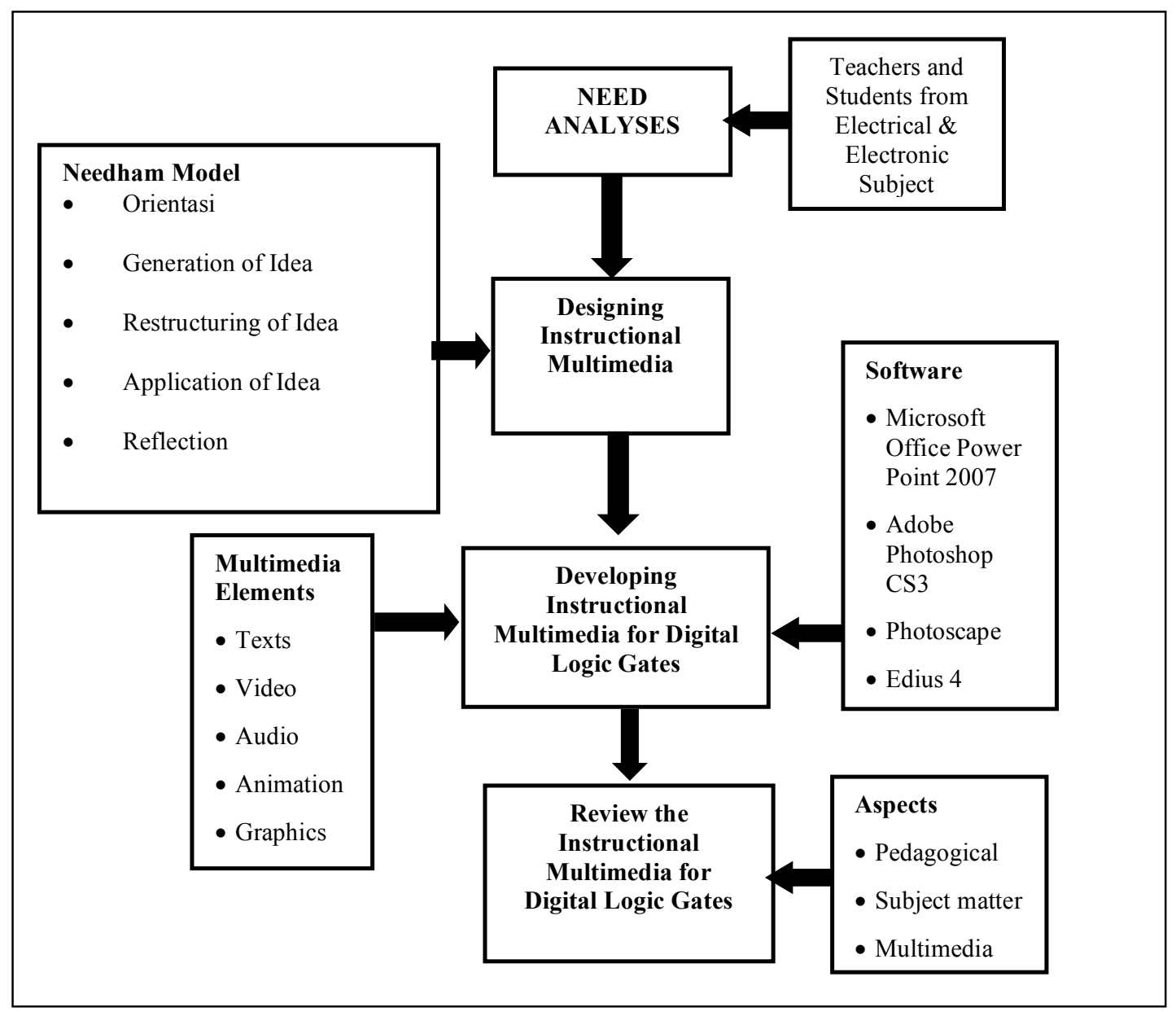

Fig. 1 : Conceptual Framework of Study

According to students' interviews, they have difficulty in mastering, remembering and understanding the concepts contained in the logic gates as they were exposed to the symbols, functions and constructs of truth tables for seven (7) types of logic gates. This finding was support by the teachers options said that the failure of a student to master this basic concept causes them not able solve the problem involving the combination logic. Teachers also note that based on their experience teaching this topic, only outstanding students can answer questions that involve this combination circuit successfully. Medium-level students can only solve the equations and parts of basic circuit output only. In addition, teachers and students also stated that the use of interactive multimedia materials in $\mathrm{L} \& \mathrm{~T}$ is able to enhance their understanding on basic concepts in this topic. Interactive multimedia materials are able to reinforce students' understanding in mastering the concept, facilitating teachers to deliver the knowledge and retain the focus of students in L\&T sessions. They also mentioned that multimedia elements in the instructional material must a combination of text, graphics, video, audio and animation.

\subsection{Development of the Instructional Multimedia Material for Digital Logic Gates}

The instructional multimedia Material for Digital Logic Gates was developed based on Needham Five Phases Model. Thus, it consists of screen for Learning Objectives, Orientation, Generation of Idea, Restructuring of Idea, Application of Idea, and Reflection as shown in Figure 2.

The Objectives Screen is displayed before the learning is started. Through this objectives screen, students are able to know the content they must mastery at the end of the lesson. The orientation screen aims to attract students' attention before the teaching takes place. For this phase, video related to logic gate is displayed as a learning induction set. The Generation of Idea screen will identify student ideas by asking students questions them about their opinion and ideas. Students are asked to think about videos that have been shown in the orientation phase. After the student respond, the teacher will provide feedback and correct the students answer. 
Table 2 - Need Analysis on Features of Instructional Multimedia Materials for Electrical \& Electronic course

\begin{tabular}{|c|c|c|c|}
\hline Constructs & Results & $\begin{array}{c}\text { Frequency of } \\
\text { Teachers Agree with } \\
\text { the Statement (total of } \\
\text { 4) }\end{array}$ & $\begin{array}{c}\text { Frequency of } \\
\text { Students Agree with } \\
\text { the Statement (total of } \\
\text { 8) }\end{array}$ \\
\hline $\begin{array}{l}\text { Topic(s) most difficult to } \\
\text { score by students }\end{array}$ & $\begin{array}{l}\text { - Number system \& Logic } \\
\text { - Bates } \\
\text { - } \text { Boolean Operation } \\
\text { - } \text { Passive Component }\end{array}$ & $\begin{array}{l}\bullet 4 \\
\bullet 4 \\
\bullet- \\
\bullet-\end{array}$ & $\begin{array}{l}\bullet 6 \\
\bullet \quad 8 \\
\bullet \quad 3 \\
\bullet 5\end{array}$ \\
\hline $\begin{array}{l}\text { Learning and Teaching } \\
\text { Methods used }\end{array}$ & $\begin{array}{ll}\text { - } & \text { Chalk \& Talk } \\
\text { - } & \text { Comment power point } \\
\text { - } & \text { } \text { Gresentation } \\
\text { - } & \end{array}$ & $\begin{array}{l}\text { - } 4 \\
\text { - } 4 \\
\text { - } 3\end{array}$ & $\begin{array}{ll}\text { - } & 8 \\
\text { - } & 6 \\
\text { - } & 6\end{array}$ \\
\hline $\begin{array}{l}\text { Learning and Teaching } \\
\text { Materials }\end{array}$ & $\begin{array}{l}\text { - } \text { Text book } \\
\text { - } \text { Comment power point } \\
\text { slide } \\
\text { - } \quad \text { Model }\end{array}$ & $\begin{array}{ll}- & 4 \\
- & 3 \\
- & 4\end{array}$ & $\begin{array}{l}\text { - } 8 \\
\text { - } 5 \\
\text { - } 4\end{array}$ \\
\hline $\begin{array}{l}\text { The needs for instructional } \\
\text { multimedia material for this } \\
\text { course }\end{array}$ & $\begin{array}{l}\text { Enhance students } \\
\text { understanding } \\
\text { - Assist teachers to deliver } \\
\text { the knowledge } \\
\text { effectively } \\
\text { - Gain attraction of } \\
\text { students }\end{array}$ & $\begin{array}{l}\text { - } 4 \\
\text { - } 3 \\
\text { - } 3\end{array}$ & $\begin{array}{l}\text { - } 8 \\
\text { - } 5\end{array}$ \\
\hline $\begin{array}{l}\text { Suggested Features for the } \\
\text { instructional multimedia } \\
\text { material }\end{array}$ & $\begin{array}{ll}\text { - } & \text { Animation } \\
\text { - } & \text { Video } \\
\text { - } & \text { Texts } \\
\text { - } & \text { Audio } \\
\text { - } & \text { Graphics }\end{array}$ & $\begin{array}{l}\text { - } 4 \\
\text { - } 3 \\
\text { - } 4 \\
\text { - } 4 \\
\text { - } 4\end{array}$ & $\begin{array}{l}\text { - } 8 \\
\text { - } 7 \\
\text { - } 8 \\
\text { - } 7 \\
\text { - } 7\end{array}$ \\
\hline
\end{tabular}

The Restructuring of Idea screen is to modify the ideas of students in order to develop new concepts. At this phase, there is an introduction to the digital logic, types of logic gates, logic gates use and integrated circuit comparisons. There are seven (7) types of logic gates that students will learn. In addition, the students will study the logic gates combination. Students will also expose with symbols, equations, functions and truth tables for logic gates. After that, student will are displayed by the animations of input and output for each logic gates. Exercise for each logic gates that have been studied will be given using interactive screen. Then, the example of logic gates usage in everyday life will be showed. There is a function to enlarging the picture to enable the user see clearer the displayed picture. Figure 3 shows the flow of learning for this phase.

The application of Idea screen aims is to modify or construct ideas in new situations. At this phase, students are exposed to activities and logic gates applications. The students will guide to perform activities. For example, step by step guide to build an electric circuit. The flow of this phases is shows in Figure 4.

The reflection screen is intended to assess students' understanding. Reflective questions are available to assess the changing ideas and skills of students. Students will expose to summary of learning content, follow by the enhancement exercise. Students are able to check the correct answer through the interactive design screen. Figure 5 shows the flow of Reflection Screen. 


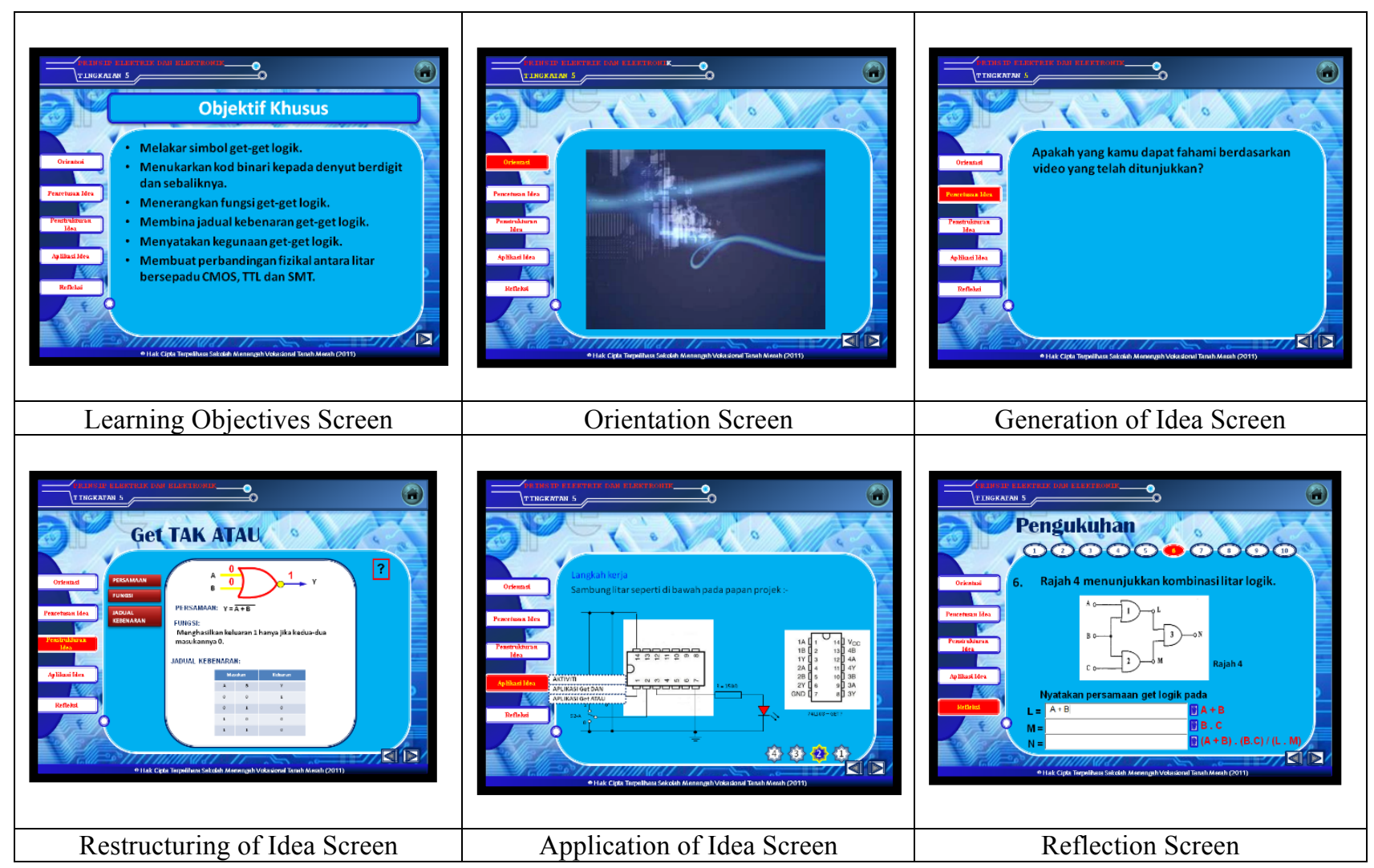

Fig. 2 - Screens consisted in Instructional Multimedia Material For Digital Logic Gates

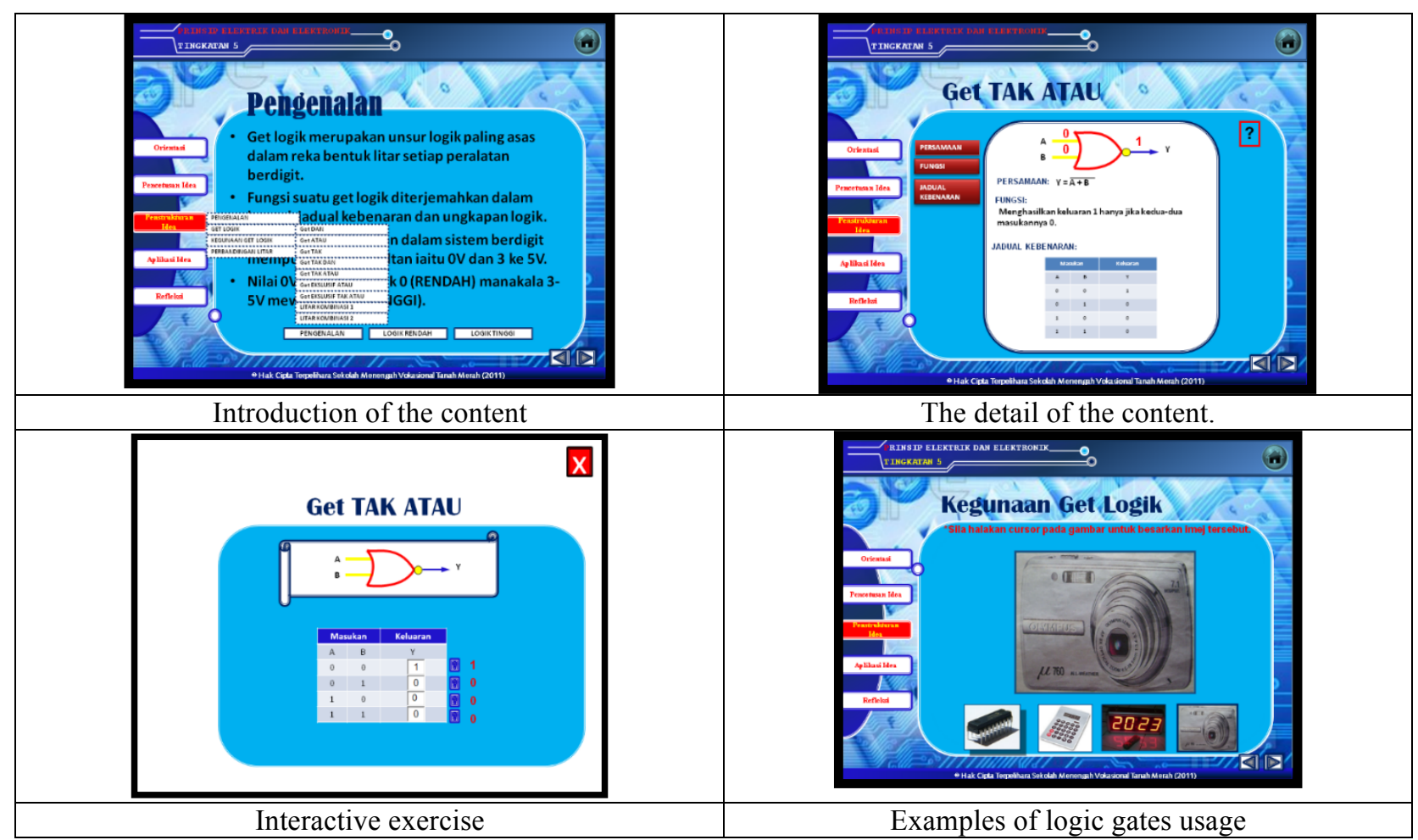

Fig. 3 - The Flow of Restructuring of Idea 

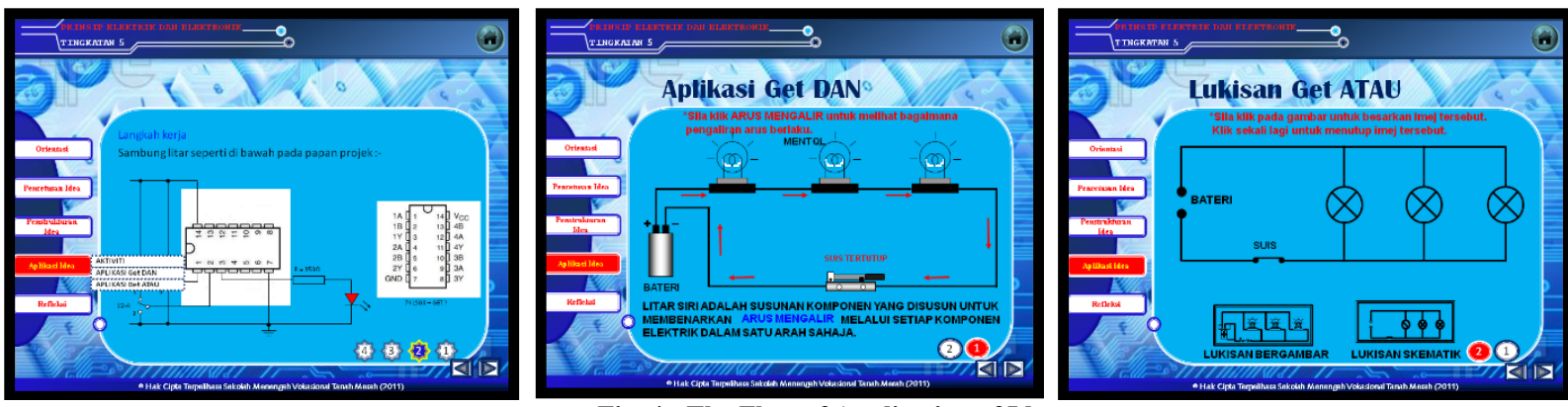

Fig. 4 - The Flow of Application of Idea
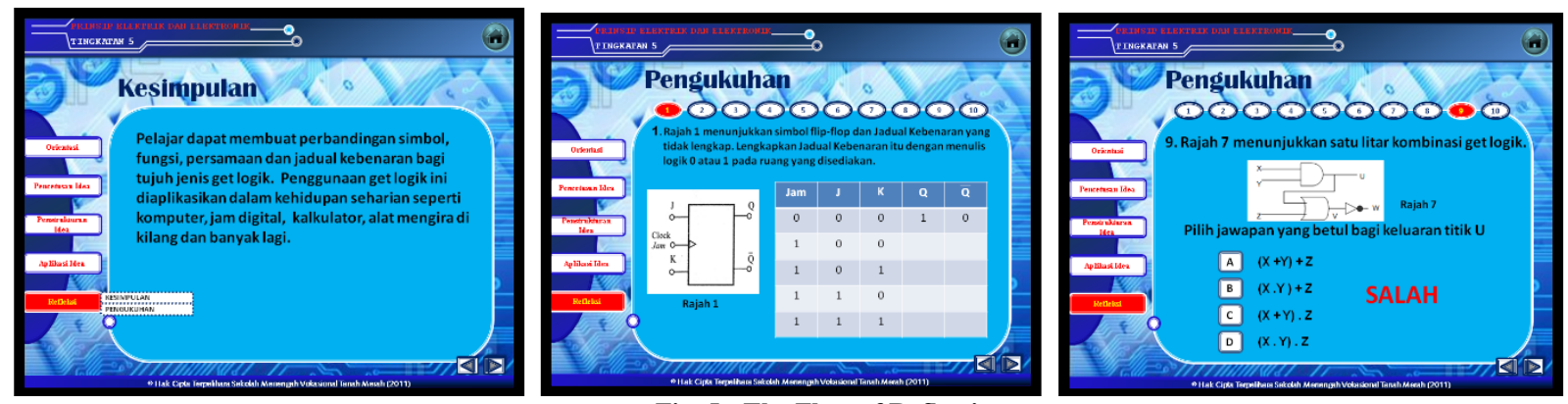

Fig. 5 - The Flow of Reflection

\subsection{Review of the Instructional Multimedia Material for Digital Logic Gates}

The review process was conducted through the interview of experts from pedagogical, subject matter and multimedia discipline. The expert in electronic digital agreed that the content and the flow of displaying the content for digital logic gates in the instructional multimedia material is correct and acceptable. The comments given by the pedagogical and multimedia experts are showed in Table 3 and 4.

Table 3 - Comments by the Pedagogical Experts

\begin{tabular}{|c|c|c|c|}
\hline NO & ITEM & Perception & Comments \\
\hline \multicolumn{4}{|c|}{ ORIENTASI PHASE } \\
\hline 1 & Introduction to topics is interesting. & Good & Fulfil the features for orientation phase in \\
\hline 2 & $\begin{array}{l}\text { The beginnings of the topics can create curiosity } \\
\text { in the students. }\end{array}$ & Good & Needham Model \\
\hline
\end{tabular}

\begin{tabular}{lll}
\hline GENERATION OF IDEA PHASE & \\
\hline 1 & $\begin{array}{l}\text { The questions are able to lead the students to Good } \\
\text { think. }\end{array}$ & $\begin{array}{l}\text { The provided activities in line with the } \\
\text { generation off idea phase. However, } \\
\text { dhe questions provided are able to help students } \\
\text { develop new knowledge by thinking to solve } \\
\text { problems. }\end{array}$
\end{tabular}

\begin{tabular}{lll}
\hline RESTRUCTURING OF IDEA PHASE & \\
\hline 1 & $\begin{array}{l}\text { Based on the questions given, students can make } \\
\text { modifications / restructuring of ideas learned in }\end{array}$ & $\begin{array}{l}\text { Fulfil the features for restructuring of idea } \\
\text { phase in Needham Model }\end{array}$
\end{tabular}

2 Students can reinforce the understanding of the Good concepts / ideas learned.

\begin{tabular}{|c|c|c|c|}
\hline \multicolumn{4}{|c|}{ APPLICATION OF IDEA PHASE } \\
\hline $\begin{array}{l}1 \\
2\end{array}$ & $\begin{array}{l}\text { Students can expand the idea in their daily life. } \\
\text { Students can develop the idea in a new situation. }\end{array}$ & $\begin{array}{l}\text { Moderate } \\
\text { Good }\end{array}$ & $\begin{array}{l}\text { Give more relevan examples for this } \\
\text { phase. }\end{array}$ \\
\hline \multicolumn{4}{|c|}{ REFFELCTION PHASE } \\
\hline 1 & $\begin{array}{l}\text { The given summary reinforces the students' } \\
\text { understanding of the lessons learned. }\end{array}$ & Good & $\begin{array}{l}\text { Fulfil the features for reflection phase in } \\
\text { Needham Model }\end{array}$ \\
\hline 2 & $\begin{array}{l}\text { The exercise provided are able to assess the } \\
\text { knowledge mastery level of student. }\end{array}$ & Good & \\
\hline
\end{tabular}


Table 4 - Comments by the Multimedia Experts

\begin{tabular}{|c|c|c|c|}
\hline NO & ITEM & Perception & Comments \\
\hline \multicolumn{4}{|c|}{ TEXTS ASPECT } \\
\hline 1 & $\begin{array}{l}\text { Text descriptions on the learning content } \\
\text { facilitate users to enhance understanding } \\
\text { level. }\end{array}$ & Good & \multirow{8}{*}{$\begin{array}{l}\text { The application of text elements in } \\
\text { interactive multimedia materials is } \\
\text { appropriate to facilitate students during L\&T } \\
\text { process. Selection of text colour should be } \\
\text { emphasized in order to make it easier for } \\
\text { students to read the text clearly }\end{array}$} \\
\hline 2 & $\begin{array}{l}\text { The language used in the instructional } \\
\text { multimedia material is easy to understand. }\end{array}$ & Good & \\
\hline 3 & $\begin{array}{l}\text { Text does not interfere with information } \\
\text { presentation in the multimedia material. }\end{array}$ & Good & \\
\hline 4 & No spelling errors & Good & \\
\hline 5 & Font used is clear. & Good & \\
\hline 6 & Fonts used are easy to read. & Good & \\
\hline 7 & The colour used for text is appropriate. & Good & \\
\hline 8 & The colour used for text is interesting. & Good & \\
\hline \multicolumn{4}{|c|}{ GRAPHIC ASPECT } \\
\hline 1 & $\begin{array}{l}\text { The graphics used help the user understand } \\
\text { the learning content. }\end{array}$ & Good & \multirow{5}{*}{$\begin{array}{l}\text { The graphics used can be more interesting by } \\
\text { using appropriate colour. The use of icon } \\
\text { that is easily identifiable to its function helps } \\
\text { users to use this material successfully. }\end{array}$} \\
\hline 2 & The graphics are clear. & Good & \\
\hline 3 & The graphics can be easily identified. & Good & \\
\hline 4 & $\begin{array}{l}\text { The colour used on the graphic in this } \\
\text { multimedia material is appropriate. }\end{array}$ & Good & \\
\hline 5 & $\begin{array}{l}\text { The icons used in this multimedia material are } \\
\text { easily identifiable off its function. }\end{array}$ & Good & \\
\hline \multicolumn{4}{|c|}{ ANIMATION ASPECT } \\
\hline 1 & $\begin{array}{l}\text { The animations used are helping to increase } \\
\text { user understanding level. }\end{array}$ & Good & \multirow{4}{*}{$\begin{array}{l}\text { The input and output animations used } \\
\text { suitable to the content learned by the } \\
\text { students. Animation for AND logic gate and } \\
\text { OR logic gate is very eye-catching. }\end{array}$} \\
\hline 2 & $\begin{array}{l}\text { The animations used help users to understand } \\
\text { the lessons learned. }\end{array}$ & Good & \\
\hline 3 & The animation used is very clear. & Good & \\
\hline 4 & Animation used is to attract user interest. & Good & \\
\hline \multicolumn{4}{|c|}{ VIDEO ASPECT } \\
\hline 1 & The videos provided are suitable to the topic. & Good & \multirow{3}{*}{$\begin{array}{l}\text { The use of video at the beginning of the } \\
\text { lesson are able to catch the interest to learn } \\
\text { for user. Videos provided are in line to the } \\
\text { learning topic. }\end{array}$} \\
\hline 2 & $\begin{array}{l}\text { The videos are helping to increase user } \\
\text { understanding level. }\end{array}$ & Good & \\
\hline 3 & The quality of video is good. & Good & \\
\hline
\end{tabular}

\section{Conclusion}

Overall, this study had achieved the targeted objectives. In conclusion, the multimedia elements used in the developed instructional media such as text, audio, video, graphics and animation able to stimulate students to increase interest and retain their focus during the L\&T process. Experts also agreed that instructional multimedia material based on Needham Model is able to enhance students' mastery level and facilitate them to understand the content delivered by teachers. Teachers are encouraged to design and develop their teaching materials by applying learning theories or instructional design models in order to create meaningful and effective L\&T processes. Future research will be conducted to test the effectiveness of this instructional multimedia material in students' achievement level for the digital logic gates topic. Furthermore, the future research will also determine the perception of end user which are teachers and students toward the instructional multimedia material from the aspects content, teaching strategy, presentation format and technical.

\section{Acknowledgement}

The publication of this work was supported by the PPG grant (Vote No.: V023) awarded by Ministry of Education Malaysia (MOE) and the Research and Management Centre (RMC) of Universiti Tun Hussein Onn Malaysia. The authors would also like to thank to those who graciously gave their time to participate in this study.

\section{References}

Ab. Halim, R. (2007). Penggunaan Model Konstruktivisme Dalam Matapelajaran Sains Pertanian. (Unpublished Thesis), Universiti Pendidikan Sultan Idris, Malaysia

Abdullah, W.S.W. (1998). Siri Buku Panduan: Pengenalan Multimedia Pendidikan. Johor: Penerbit UTM. 
Laz, H.A. \& Shafei, K.E. (2016). The Effectiveness of Constructivist Learning Model in the Teaching of Mathematics. Journal of Applied and Industrial Sciences, 2(3), 106-109. Retrieved from http://researchpub.org/journal/jais/number/vol2-no3/vol2-no3-3.pdf

Lee, M.F. \& Zainal, N.A. (2018). Development of Needham Model Based e-Module for Electromagnetic Field \& Wave. Proceeding of 2017 IEEE Conference on International Industrial Engineering and Engineering Management (IEEM) . Retrivied from https://ieeexplore.ieee.org/document/8289863

Leinsin, E.D. (2007). Pembinaan Perisian Multimedia Pendidikan Berasaskan Model Konstruktif Needham Lima Fasa Bagi Tajuk Momentum Dalam Mata Pelajaran Fizik Tingkatan Empat (Unpublished Final Year Project), Universiti Teknologi Malaysia, Malaysia

Maheshwari, G. \& Thomas, S. (2017). An Analysis Of The Effectiveness Of The Constructivist Approach In Teaching Business Statistics. Informing Science: The International Journal of an Emerging Transdisciplinary, 20, 83-97. Retrieved from http://www.inform.nu/Articles/Vol20/ISJv20p083-097Maheshwari3491.pdf

Marimutu, T. (2004). An Insight into Constructivism and Discovery Inquiry in the Teaching of Science by Secondary School Trainee Teachers during Practicum. Prosiding Seminar Penyelidikan Pendidikan MPBL.

Nail, S. \& Muthiah, M. (2005), Penggunaan Model Lima Fasa Needham Dalam Pembelajaran Sejarah. Jurnal Pendidik dan Pendidikan, 20, 21-41.

Needham, R. \& Hill, P. (1987). Teaching Strategies for Developing Understanding in Science. Children's Learning in Science Project, Centre for Studies in Science and Mathematics Education, The University of Leeds, Leeds LS2 9JT England, United Kingdom.

Qarareh, A.O. (2016). The Effect of Using the Constructivist Learning Model in Teaching Science on the Achievement and Scientific Thinking of 8th Grade Students. International Education Studies, 9 (7), Retrived from https://files.eric.ed.gov/fulltext/EJ1106532.pdf

Samin, H. \& Mustapha, R. (2005). “E-Pembelajaran: Sistem Kehakiman Di Malaysia”. Prosiding Seminar Kebangsaan E-Komuniti 2005. 1-16.

Zain, I. (2002). Aplikasi Multimedia Dalam Pengajaran. Kuala Lumpur: Utusan Publications \& Distributors Sdn. Bhd. 